\title{
A Comparison of Sap Flow Measurements and Potometry in Two Tropical Lowland Tree Species with Contrasting Wood Properties
}

\author{
Marco V. Gutiérrez ${ }^{*}$ \& Louis S. Santiago ${ }^{2,3}$ \\ 1 Universidad de Costa Rica, Estación Experimental Fabio Baudrit, Alajuela, Costa Rica. \\ 2 University of Hawaii, Department of Botany, Honolulu, HI, 96822 USA. \\ 3 Present address: University of Florida, Department of Botany, 220 Bartram Hall, P.O. Box 118526, Gainesville, FL \\ 32611-8526, USA. \\ * Corresponding author: Universidad de Costa Rica, Facultad de Agronomía, San José, Costa Rica. Phone: (506) 433- \\ 9111. Fax: (506) 433-9086; surdo26@racsa.co.cr
}

Received 31-V-2002. Corrected 13-VII-2005. Accepted 16-XII-2005.

\begin{abstract}
We evaluated the performance of the Heat Dissipation Technique (HDT) to measure sap flow in whole trees by comparison with potometric water uptake. Two tropical lowland species, Ochroma lagopus (balsa), a pioneer species with light wood and Hyeronima alchorneoides (pilón), a late-successional species with hard wood were examined. Diurnal courses of sap flow measured with the HDT showed good agreement with potometry. At the low sap flow rates (below $1 \mathrm{Kg} \mathrm{h}^{-1}$ ) occurring during nocturnal recharge HDT consistently underestimated sap flow rates. This resulted in the failure of the current version of the HDT to measure nocturnal water uptake, an important component of the water budget of at least one of the two species examined. Rev. Biol. Trop. 54(1): 73-81. Epub 2006 Mar 31.
\end{abstract}

Key words: heat dissipation technique, nocturnal uptake, potometer, tropical trees, sap flow, stomatal conductance, wood density.

Current interest in measuring the exchange of water (and carbon dioxide) between whole ecosystems and the atmosphere has resulted in an increasing need to accurately measure fluxes at the whole tree level for analysis at larger scales. The development and refinement of techniques involving trunk sector heat balance (Cermask et al. 1973), stem heat balance (Sakuratani 1981), heat pulses (Closs 1958, Marshall 1958), and heat dissipation (Granier 1985) to measure whole plant water use have followed because of their inexpensive and non-destructive nature.

Heat dissipation has been especially promising to those wishing to measure water use in very large trees growing in the field. In contrast to heat balance methods (see Herzog et al. 1997), heat dissipation techniques have performed well in model systems as well as under field conditions (Vertessy et al. 1997). Errors due to radial (Phillips et al. 1996) and angular (Cabibel et al. 1997) variations in sap flow velocity, and to the determination of the conducting xylem area (Phillips et al. 1996) have been previously examined. Sap flow estimates based on heat dissipation measurements have shown errors in the range of 2-12\% (Wullschleger et al. 1998). However, because of the empirical assumptions involved in these approaches, it is important to address divergences between measurements obtained by different techniques.

Our objective was to test the capacity of the Heat Dissipation Technique to accurately measure water use of tropical trees, by comparing it with water uptake of trees held in potometers. Potometers are a useful tool for measuring water uptake (Fig. 1), facilitating 


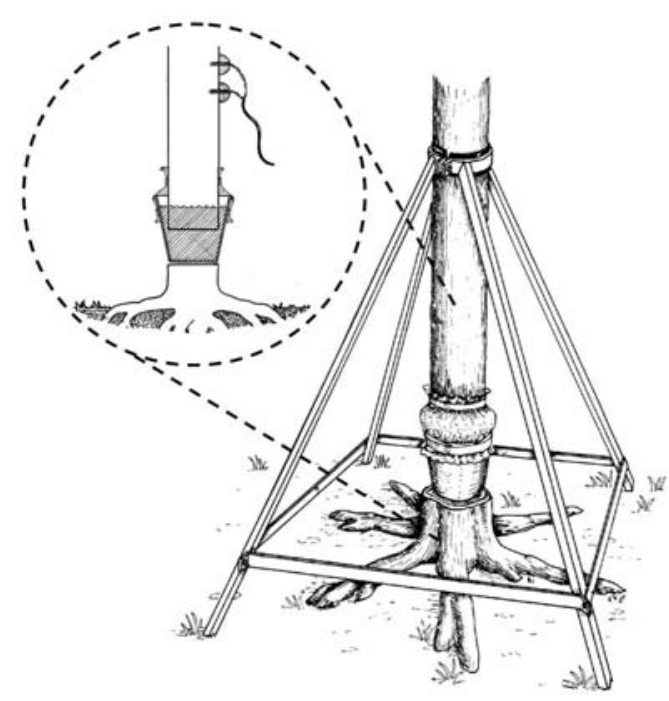

Fig. 1. Schematic diagram of a potometer system consisting of an excised tree with its base immersed in a water reservoir. The tree stem was suspended with a large metallic frame. The inset shows a closer view of the potometer tree on which Granier probes were implanted at approximately $1 \mathrm{~m}$ above the cut.

comparisons with other techniques (Knight et al. 1981, Vertessy et al. 1997). We also hoped to gain information on whether HDT can detect nocturnal water movement since the technique relies on the occurrence of zero flow during the night to calculate daily rates (Granier 1985). Because of the low rates typically associated with nocturnal uptake (Green et al. 1989), and the influence of wood density and stem capacitance on this process (Waring and Running 1978, Goldstein et al. 1997), a specific objective was to asses the capacity of HDT to measure stem recharge in trees with contrasting wood properties.

\section{MATERIALS AND METHODS}

\section{Experimental site and plant materia:} The experiment was carried out at La Selva Biological Station (Organization for Tropical Studies) in the northern lowlands of Costa Rica, at an elevation of approximately $40 \mathrm{~m}$ and an average temperature of $24^{\circ} \mathrm{C}$. Annual precipitation is approximately $4000 \mathrm{~mm}$ with a short drier season in February-March. The site is on an alluvial terrace with a deep, welldrained fertile soil. Experiments were conducted on Ochroma lagopus (Bombacaceae) and Hyeronima alchorneoides (Euphorbiaceae) growing in plantations. Details of the establishment of the experimental plantations are given by Haggar and Ewel (1995). Experiments on Ochroma were conducted from 25-29 March, 1997, and observations on Hyeronima were conducted from 12-16 June, 1997.

Ochroma is a very common, fast-growing pioneer species and the source of the lightest of commercial woods. Basic specific gravity (ovendry weight/fresh volume) is 0.10 to $0.17 \mathrm{~g} \mathrm{~cm}^{-3}$ (Chudnoff 1984). The hartwood is pale brown or reddish and the sapwood, which comprises most of the commercial timber is nearly white (Chudnoff 1984). It exhibits no distinct growth rings in its cross section (Whitmore 1983).

Hyeronima is an evergreen, late successional hardwood. No periodicity in growth increment is observed (L. Newsom, unpublished data). The hartwood is a light reddish brown to dark red and the sapwood is pinkish white and 2 to $5 \mathrm{~cm}$ wide. Basic specific gravity is 0.60 to $0.67 \mathrm{~g} \mathrm{~cm}^{-3}$ (Chudnoff 1984).

Two-year old Ochroma and four-year old Hyeronima trees were selected. Two trees of each species were chosen for potometers and two more trees were kept as controls. Ochroma trees were approximately $18 \mathrm{~m}$ tall, and Hyeronima trees were 15 to $16 \mathrm{~m}$ tall at the time of the experiment. For Ochroma, diameter at $1.5 \mathrm{~m}$ height was 9.9 and 13.6 $\mathrm{cm}$ for control trees, and 13.5 and $15.2 \mathrm{~cm}$ for trees in potometers. For Hyeronima, diameter at $1.5 \mathrm{~m}$ was 15.6 and $18.3 \mathrm{~cm}$ for control trees, and 12.0 and $12.6 \mathrm{~cm}$ for trees in potometers.

Sap flow measurements: We used the heat dissipation technique (HDT; Granier 1985) to measure sap flow of intact trees and trees installed in potometers. This technique measures the temperature of a line heat source implanted in the sapwood of a tree, referenced 
to the sapwood temperature measured $2 \mathrm{~cm}$ below the heated needle. The probe measures the sapwood heat dissipation, which increases with sap flow and the resultant cooling of the heat source. When the sap flow velocity is minimal, the temperature difference (dT) between the two sensors is maximal $\left(\mathrm{dT}_{\text {max }}\right)$. For practical purposes, $\mathrm{dT}_{\max }$ is assumed to correspond to zero flow. When flow increases, $\mathrm{dT}$ between the two sensors decreases. This approach enables the measurement of sap flow velocity with inexpensive equipment from the empirical relationships between $\mathrm{dT}$ and sap velocity as defined by a dimensionless parameter K (Granier 1985):

$$
K=\frac{\left(d T_{\max }-d T\right)}{d T}
$$

Granier also found empirically that the average sap flow velocity $\mathrm{V}\left(\mathrm{cm} \mathrm{s}^{-1}\right)$ could be related to $\mathrm{K}$ by an exponential expression:

$$
V=0.00199 \cdot K^{1.231}
$$

To convert velocity to sap flow rate, one uses:

$$
F_{s}=A_{s} \cdot V \cdot 3600
$$

Where $\mathrm{F}_{\mathrm{S}}$ is sap flow rate $\left(\mathrm{cm}^{3} \mathrm{~h}^{-1}\right), \mathrm{A}_{\mathrm{S}}$ is the cross-sectional area of conducting sapwood $\left(\mathrm{cm}^{2}\right)$ and 3600 has units of $\mathrm{s} \mathrm{h}^{-1}$. Typical midday values for $\mathrm{V}$ range from 10 to $80 \mathrm{~cm} \mathrm{~h}^{-1}$ (Granier 1985, Granier et al. 1992, Vertessy et al. 1997, Becker 1998).

Nocturnal water uptake was calculated using the same empirical relation described above. In water-storing tree stems, nocturnal stem recharge is expected to cause dT values to reach their typical nocturnal plateau later than in non-water storing stems. The $\mathrm{dT}_{\max }$ values observed during the night once dT had reached its pre-dawn plateau was considered $\mathrm{dT}_{\max }$. Values of nocturnal water uptake were summed for the periods between 1800 and $0600 \mathrm{~h}$.

We used 30-mm long heat dissipation probes (Model TS30; Dynamax Inc., Houston, TX) implanted at $1.5 \mathrm{~m}$ height on the stems of intact trees and approximately $1 \mathrm{~m}$ above the cut in potometer trees. We placed two sets of probes in each tree on opposite sides of the stem. The probes were operated through a datalogger (Model CR10X; Campbell Scientific, Inc., Logan, UT) programmed to obtain hourly averages of sap flow. Insulation was applied to prevent the development of environmentally induced stem temperature gradients capable of affecting the performance of the probes (Gutiérrez et al. 1994).

Microclimatic conditions were measured by an automated weather station. Relative humidity and air temperature were measured with a shielded temperature/humidity sensor (Model HMP35C; Vaisala, Inc., Helsinki, Finland). Photosynthetically active radiation (PAR at $400-700 \mathrm{~nm}$ ) was measured with a quantum sensor (Model 190S; Li-Cor, Inc., Lincoln, NE). Data were recorded every $15 \mathrm{~s}$ and averaged every hour with a datalogger (Model 21X; Campbell Scientific, Logan, UT). Volumetric soil water content was measured with a TDR Trase System (Model 6050X1; SoilMoisture, Santa Barbara, CA). Soil water content measurements were obtained using 3 sets of $0.5 \mathrm{~m}$ long stainless steel rods located in the neighborhood of the experimental trees.

Potometry: Large metallic frames (Knight et al. 1981) were attached to the potometer trees at approximately $1.75 \mathrm{~m}$ height. Guy cables additionally secured the potometers to neighboring trees to avoid tipping. The bases of the selected tree stems were cleaned and cut at $0600 \mathrm{~h}$ before any sign of sap flow was observed in the control trees, reducing the risk of xylem embolism upon cutting. The trees were placed in potometers by making two cuts near the base with a chainsaw, so that a stem segment could be removed and a water reservoir placed between the tree stump and the suspended stem. The whole operation usually took less than 5 min.

Cut trees in potometers had their bases in 101 reservoirs containing a solution of formaldehyde $(0.05 \%)$ to delay the development of microorganisms and plugging of the xylem 
(Sperry et al. 1988). The reservoir was covered with a plastic film to prevent evaporation and refilled every hour from 0600 to $1800 \mathrm{~h}$, and the amount of water added each time was recorded as uptake. Any water uptake occurring after $1800 \mathrm{~h}$ and before $0600 \mathrm{~h}$ of the next day was considered nocturnal and measured at $0600 \mathrm{~h}$.

At the end of the observation period, the trees were fed with a solution of Saphranin dye $(1 \%)$ to determine the area of conducting sapwood. Twenty-four $\mathrm{h}$ later the trees were dissected to determine the conducting sapwood area of the stem. The extent of stained tissue in stem cross-sections was traced onto paper and its area was measured with a portable area meter (Model 3100, Li-Cor, Inc.) and results revealed that all sapwood was conductive (Table 1).

Leaf water potential and stomatal conductance: In order to evaluate whether trees in potometers behaved similarly to intact trees, we conducted leaf-level measurements of water status. Sixteen-m tall construction scaffolds were used to access the canopy of the experimental trees. Pre-dawn and mid-day bulk leaf water potential $\left(\Psi_{\mathrm{L}}\right)$ measurements were taken on intact trees and trees in potometers. $\Psi_{\mathrm{L}}$ was measured using a Scholander pressure chamber
(Model 1000; PMS, Inc., Corvallis, OR) according to the protocol of Ritchie and Hinckley (1975). Leaves small enough to fit within the pressure chamber were selected, which sometimes required the sampling of leaves not fully expanded since Ochroma leaves are extremely large. Six leaves were sampled from each tree at every measurement period. Selected leaves were enclosed in plastic bags before excision, cut, and placed in a cooler for a period no longer than 30 min until they were measured in the pressure chamber.

Diurnal courses of stomatal conductance $\left(g_{S}\right)$ were taken on leaves of intact trees and trees in potometers, using a steady-state porometer (Model 1600; Li-Cor, Inc.). Six young, fully expanded sun leaves located at the top of the canopy were labeled on each tree and measured during the course of two consecutive days.

\section{RESULTS AND DISCUSSION}

Microclimatic conditions: Environmental conditions during the experiment on Ochroma were characterized by clear skies and high evaporative demand (Fig. 2). Observations on Hyeronima were conducted during partly

TABLE 1

Diameter at $1.5 \mathrm{~m}$ height (DBH), conducting sapwood area and pre-dawn and mid-day values (mean $\pm S D$ ) of bulk leaf water potential $\left(\Psi_{L}\right)$ of Ochroma and Hyeronima control and potometry trees

\begin{tabular}{|c|c|c|c|c|}
\hline Species & $\begin{array}{l}\mathrm{DBH} \\
(\mathrm{cm})\end{array}$ & $\begin{array}{c}\text { Sapwood Area } \\
\left(\mathrm{cm}^{2}\right)\end{array}$ & $\begin{array}{l}\text { Pre-dawn } \Psi_{\mathrm{L}} \\
\quad(\mathrm{MPa})\end{array}$ & $\begin{array}{l}\text { Mid-day } \Psi_{L} \\
\quad(\mathrm{MPa})\end{array}$ \\
\hline
\end{tabular}

Ochroma

$\begin{array}{lcc}\text { Control 1 } & 9.9 & 69.91 \\ \text { Control 2 } & 13.5 & 116.19 \\ \text { Potometer 1 } & 13.6 & 114.02 \\ \text { Potometer 2 } & 15.6 & 149.39 \\ \text { Hyeronima } & & \\ \text { Control 1 } & 15.5 & 176.11 \\ \text { Control 2 } & 18.3 & 247.01 \\ \text { Potometer 1 } & 12.0 & 102.04 \\ \text { Potometer 2 } & 12.6 & 113.17\end{array}$

$$
\begin{aligned}
& -0.20 \pm 0.03 \\
& -0.27 \pm 0.08 \\
& -0.21 \pm 0.04 \\
& -0.49 \pm 0.07
\end{aligned}
$$$$
-0.77 \pm 0.08
$$$$
-0.89 \pm 0.06
$$$$
-0.94 \pm 0.18
$$$$
-1.33 \pm 0.19
$$

\section{Hyeronima}

Control 1

76.11

$-0.22 \pm 0.02$

$-1.00 \pm 0.06$

$-0.21 \pm 0.04$

$-1.08 \pm 0.04$

Potometer 2

113.17

$-0.21 \pm 0.03$

$-0.90 \pm 0.07$

$-0.23 \pm 0.02$

$-0.91 \pm 0.04$ 


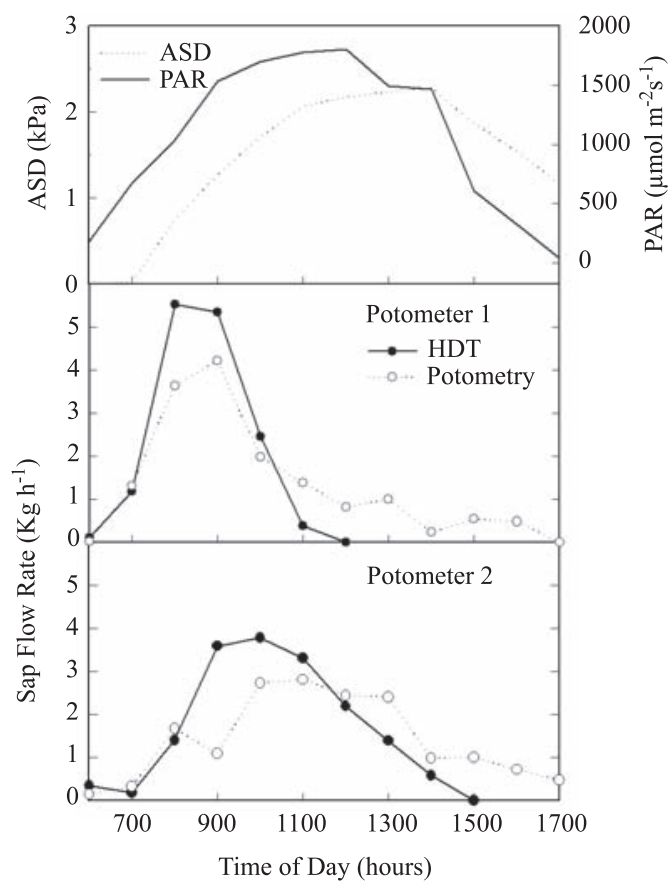

Fig. 2. Diurnal courses of atmospheric saturation deficit (ASD), photosynthetically active radiation (PAR) and sap flow rate measured using the HDT and potometry in two Ochroma lagopus trees during the first day of observations.

cloudy skies and high evaporative demand (Fig. 3). For all experiments, maximum PAR flux rates were between 1500 and $1900 \mu \mathrm{mol}$ $\mathrm{m}^{-2} \mathrm{~s}^{-1}$ and peak atmospheric saturation deficit (ASD) ranged from 1.5 to $2.5 \mathrm{kPa}$. These conditions favored the maintenance of high sap flow rates in the xylem of the tall trees used in this study. Heavy rain fell only during the night at least once during each experimental period. Volumetric soil water content in the top $50 \mathrm{~m}$ was $43 \%$ and $36 \%$ during experiments with Ochroma and Hyeronima, respectively.

Sap flow and potometry: Total daily water use by intact trees of both species examined was a function of size (Tables 1 through 3 ). Trees held in potomers showed higher total daily water uptake than intact trees of similar size, which was attributed to differences in leaf area; this trend was more pronounced in the lightwood Ochroma than in the hardwood Hyeronima (Tables 1 and 2).

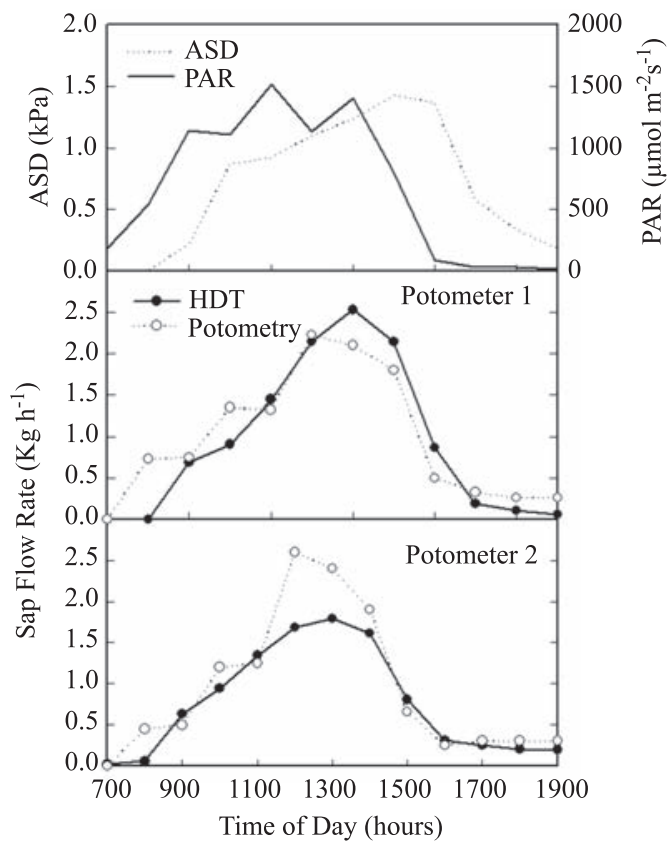

Fig. 3. Diurnal courses of atmospheric saturation deficit (ASD), photosynthetically active radiation (PAR), and sap flow rate measured using the HDT and potometry in two Hyeronima alchorneoides trees during the first day of observations.

Diurnal courses of sap flow measured using the HDT showed good agreement with potometric measurements (Figs. 2 and 3). This good agreement persisted for as long as $g_{S}$ and $\Psi_{L}$ of trees in potometers were similar to those observed in intact trees (Fig. 4, Table 3). Some divergences were observed during peak hourly sap flow rates and under low flow conditions such as those found in wilting Ochroma trees and during nocturnal water uptake (Table 1).

A very close agreement between the two techniques was found along the course of two days of observation during which Hyeronima trees in potometers did not show any visible signs of wilting (Table 2). Potometric determinations of total daily tree water use in Hyeronima were slightly higher than sap flow estimates (Table 2). At peak sap flow rates ( 2 to $2.5 \mathrm{Kg} \mathrm{h}^{-1}$ ) observed between 1200 and $1400 \mathrm{~h}$, HDT diverged more from potometric water uptake than at lower flow rates (Fig. 3). Measurements of $g_{S}$ and $\Psi_{L}$ confirmed that the 
TABLE 2

Total daily and nocturnal sap flow of Ochroma lagopus control and potometry trees during three consecutive days of observation

\begin{tabular}{|c|c|c|c|c|c|c|}
\hline \multirow[t]{2}{*}{$\begin{array}{l}\text { Total Daily } \\
\text { Flow (Kg) }\end{array}$} & \multicolumn{2}{|c|}{ Day 1} & \multicolumn{2}{|c|}{ Day 2} & \multicolumn{2}{|c|}{ Day 3} \\
\hline & HDT & Potometry & HDT & Potometry & HDT & Potometry \\
\hline Control 1 & 1.82 & --- & 2.86 & -- & 5.94 & -- \\
\hline Control 2 & 7.82 & --- & 9.21 & --- & 5.45 & -- \\
\hline Potometer 1 & 14.99 & 15.63 & 2.59 & 4.78 & 1.10 & 3.65 \\
\hline Potometer 2 & 16.76 & 16.76 & 9.06 & 10.81 & 5.61 & 5.15 \\
\hline \multirow[t]{2}{*}{$\begin{array}{l}\text { Total Nocturnal } \\
\text { Flow (Kg) }\end{array}$} & \multicolumn{2}{|c|}{ Night 1} & \multicolumn{2}{|c|}{ Night 2} & \multicolumn{2}{|c|}{ Night 3} \\
\hline & HDT & Potometry & HDT & Potometry & HDT & Potometry \\
\hline Control 1 & 1.05 & --- & 0.46 & --- & 0.10 & --- \\
\hline Control 2 & 0.05 & --- & 0.40 & --- & 0.38 & --- \\
\hline Potometer 1 & 1.25 & 2.90 & 0.83 & 2.70 & 0.79 & 2.40 \\
\hline Potometer 2 & 7.82 & 1.55 & 2.47 & 1.52 & 10.90 & 1.60 \\
\hline
\end{tabular}

experimental trees were performing similarly to control trees (Fig. 4; Table 3).

The patterns were more complex in Ochroma. In this lightwood tree, the agreement between measurements of total daily water uptake obtained by the two methods was also remarkably good, particularly under conditions of high sap flow rates observed during

TABLE 3

Total daily and nocturnal sap flow of Hyeronima alchorneoides control and potometry trees during two consecutive days of observation

Total Daily Flow $(\mathrm{Kg})$

Control 1
Control 2
Potometer 1
Potometer 2
Total Nocturnal Flow $(\mathrm{Kg})$

Control 1

Control 2

Potometer 1

Potometer 2
Day 1

HDT

8.11

31.47

9.68

11.12

Night 1

HDT

0.08

1.68

1.17

0.13
Potometry
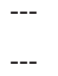

11.82

11.62
Day 2

\begin{tabular}{rc}
\multicolumn{1}{c}{ HDT } & Potometry \\
8.19 & --- \\
36.78 & --- \\
7.44 & 9.50 \\
9.82 & 10.34
\end{tabular}

Night 2

HDT

1.01

2.91

0.74

0.24

Potometry

$\begin{array}{cc}--- & 1.01 \\ --- & 2.91 \\ 0 & 0.74 \\ 0 & 0.24\end{array}$

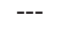
$--$
0.48
0.31 
the first day of observations (Fig. 2; Table 1). As in Hyeronima, potometric determinations of total daily water use during three days of observations were higher than HDT estimates. However, at peak sap flow rates (4 to $5 \mathrm{Kg} \mathrm{h}^{-1}$ ) observed during the morning hours, and in contrast to the pattern observed in Hyeronima, HDT overestimated potometric water uptake in Ochroma (Fig. 2). This pattern was reversed during the afternoon when lower sap flow rates (less than $2 \mathrm{Kg} \mathrm{h}^{-1}$ ) prevailed; at such low flows, HDT consistently underestimated actual sap flow rates (Fig. 2).

The dT values typically observed in the low wood density Ochroma were generally higher than dT measured in the hardwood Hyeronima (data not shown). This could be the result of abundant air spaces in Ochroma wood (Chudnoff 1984) which could dissipate heat more slowly than water-filled sapwood. Since this technique assumes that the probes are in contact with the conducting sapwood, the presence of these air spaces could amplify the error in the measurement of sap flow in species with very low wood densities, and may account for the night time fluctuations in dT observed in Ochroma.

The larger Ochroma tree in potometer 2 $(\mathrm{DBH}=15.6 \mathrm{~cm})$ exhibited visible signs of wilting by $1000 \mathrm{~h}$ of the first day of observation. The remaining potometer Ochroma remained turgid but experienced increasing water stress as the experiment progressed (Table 1). As indicated above, wilting was not observed in Hyeronima trees, which maintained high water status during the course of two days of observations (Table 2).

Sap flow rates in Ochroma decreased earlier than in Hyeronima. A pronounced reduction in sap flow to values lower than $1 \mathrm{Kg} \mathrm{h}^{-1}$ was observed by 1000 to $1100 \mathrm{~h}$, even though PAR and ASD remained high during the rest of the afternoon (Fig. 2). In Hyeronima trees, in contrast, diurnal sap flow courses measured at $1.5 \mathrm{~m}$ height showed a strong dependence on PAR courses, and lagged behind PAR by approximately 1 to $2 \mathrm{hr}$ (Fig. 3). Sap flow at $1.5 \mathrm{~m}$ height rose only after $0800 \mathrm{~h}$ and peaked between 1200 and $1400 \mathrm{~h}$, and remained high for a large part of the afternoon. Transpiration in Hyeronima remained at peak rates later in the day and followed ASD more closely in the afternoon.

Leaf water potential and stomatal conductance: In Ochroma, leaves of the control trees exhibited average predawn and midday $\Psi_{\mathrm{L}}$ values of -0.24 and $-0.83 \mathrm{MPa}$, while leaves from trees in potometers reached $\Psi_{\mathrm{L}}$ values of -0.35 and $-1.13 \mathrm{MPa}$ (Table 3 ), respectively. One wilting balsa tree remarkably recovered during the night to exhibit average predawn $\Psi_{\mathrm{L}}$ values very similar to those of control trees (data not shown). In Hyeronima, average pre-dawn $\Psi_{\mathrm{L}}$ values of leaves of control trees $(-0.215 \mathrm{MPa})$ and trees in potometers $(-0.22 \mathrm{MPa})$ did not differ. Average midday $\Psi_{\mathrm{L}}$ values of leaves of control trees $(-1.04 \mathrm{MPa})$ were virtually indistinguishable from $\Psi_{\mathrm{L}}$ values of leaves of trees in potometers $(-0.91 \mathrm{MPa})$.

The diurnal trend as well as the maximum $g_{S}$ values of control trees and trees in potometers of the two species examined were virtually indistinguishable during the first day of observations (Fig. 4). In Ochroma potometers only, $g_{S}$ showed the first signs of reduction during the afternoon of the first day (Fig. 4), and drastically decreased during the second day of observation as compared to control trees (data not shown), which resulted in progressively lower values of total tree water use during the course of the experiment (Table 1). Despite the precautions employed to control microbial growth, it is likely that high temperatures and the severity of the operations performed on the potometric trees favored progressive xylem dysfunction.

Average and maximum $g_{S}$ values of both the hardwood Hyeronima and the lighter Ochroma were similar. Maximum $g_{S}$ values in the order of 1.3 and $0.8 \mathrm{~mol} \mathrm{~m}^{-2} \mathrm{~s}^{-1}$ were observed between 0800 and $1000 \mathrm{~h}$ in Ochroma and Hyeronima, respectively. After this time, $g_{S}$ declined during the rest of the day and behaved similarly for both species (Fig. 4). 


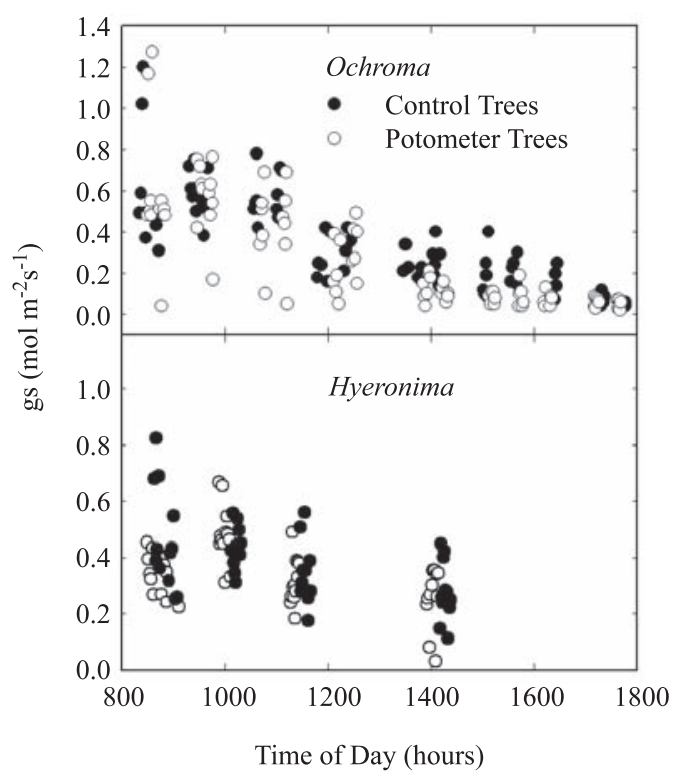

Fig. 4. Diurnal courses of stomatal conductance $\left(g_{S}\right)$ of Ochroma lagopus and Hyeronima alchorneoides. Six leaves from control ( $\bigcirc$ ) and potometry $(\bigcirc)$ trees were sampled at each time during the course of the day. Every point represents on measurement of stomatal conductance taken on fully expanded, upper canopy leaves.

De-rooted trees held in potometers exhibited similar trends in stomatal behavior.

Nocturnal water uptake: Our potometric measurements indicate that both species exhibited nocturnal water uptake (Tables 1 and 2). Nocturnal water uptake was an important fraction of diurnal water uptake in Ochroma, but less so in Hyeronima. Nocturnal water uptake in Ochroma ranged from 1.5 to 2.91 and was apparently responsible for the recovery of wilting trees during consecutive nights. However, HDT performed poorly at measuring nocturnal water uptake, as estimates did not show any consistent relationship with the values measured in potometer trees (Tables 1 and 2).

Possible reasons underlying the failure of HDT to measure low flows have been recently discussed by Becker (1998) in relation to heat pulse techniques. Sources of error have been related to problems of contact between the probes and the sapwood, and to the low thermal conductivity of the materials currently employed in probe construction.

The magnitude of nocturnal uptake as a proportion of the water budget can be considerable (Green et al. 1989), and has been frequently implicated in xylem recovery from cavitation (Pickard 1989) and recharge of stem capacitance (Waring and Running 1978, Knight et al. 1981, Goldstein et al. 1997). However, the techniques currently available to measure sap flow rates in stems appear to perform poorly under the low flows typically associated to nocturnal water uptake (Becker 1998).

\section{CONCLUSIONS}

The results of our comparison suggest that HDT represents a useful method for estimating transpiration rates above $1.0 \mathrm{Kg} \mathrm{h}^{-1}$ in large trees. In Ochroma, error values relative to potometry ranged between $4 \%$ in actively transpiring individuals (Day 1 in Table 1) to $70 \%$ at low flow rates observed in wilting trees (Day 3 in Table 1). In Hyeronima, maximum error values observed were in the order of $20 \%$.

In its current version, the HDT is not useful to measure low flows such as those commonly found at night, or in wilting and shaded plants. Nocturnal water uptake was an important component of the water budget of the tree species examined, particularly of Ochroma, whose recovery from wilting seemed to be related to high rates of nocturnal water uptake.

\section{ACKNOWLEDGMENTS}

This research was supported by grants D/2462-1 from the International Foundation for Science (Sweden) and the Mellon Foundation to M.V. Gutiérrez, and a STRI-OTS Tropical Exploratory award to L.S. Santiago. We gratefully acknowledge the collaboration of Jack Ewel, Miguel Cifuentes and the Huertos Project staff at La Selva for their help during field work 
and data collection. We thank F.C. Meinzer and S.M. Mulkey for helpful comments on an earlier draft of the manuscript.

\section{REFERENCES}

Becker, P. 1998. Limitations of a compensation heat pulse velocity system at low sap flow: implications for measurements at night and in shaded trees. Tree Physiol. 18: 177-84.

Cabibel, B., C. Isbérie \& J. Horoyan. 1997. Flux de seve et alimentation hydrique de cerisiers irrigués ou non en localisation. Agronomie 17: 97-112.

Cermaऽk, J., M. Deml, \& M. Penka. 1973. A new method of sap flow determination in trees. Biologia Plantarum 15: 171-8.

Chudnoff, M. 1984. Tropical Timbers of the World. USDA., Forest Service, Agriculture Handbook No. 607.

Closs, R.L. 1958. The heat pulse method for measuring rate of sap flow in plant stems. New Zealand J. Sci. 1: $281-8$

Goldstein, G., J.L. Andrade, F.C. Meinzer, N.M. Holbrook, P. Jackson, J. Cavelier \& A. Celis. 1997. Stem water storage and diurnal patterns of water use in tropical forest trees. Plant, Cell \& Environ. 21: 397-406.

Granier, A. 1985. Une novelle methode pour la mesure du flux de seve brute dans le tronc des arbres. Ann. Sci. Forest: 42: 193-200

Granier, A., R. Huc \& F. Colin. 1992. Transpiration and stomatal conductance of two rainforest species growing in plantations (Simarouba amara and Goupia glabra) in French Guyana. Ann. Sci. Forest. 49: 17-24.

Green, S.R., K.G. McNaughton \& B.E. Clotier. 1989. Observations of night-time water use in kiwifruit vines and apple trees. Agri. Forest Meteorol. 48: 251-61.

Gutiérrez, M.V., R.A. Harrington, F.C. Meinzer \& J.H. Fownes. 1994. The effect of environmentally induced stem temperature gradients on transpiration estimates from the heat balance method in two tropical woody species. Tree Physiol. B: 179-90.

Haggar, J.P. \& J.J. Ewel. 1995. Establishment, resource acquisition and early productivity as determined by biomass allocation patterns of three tropical tree species. Forest Sci. 41: 681-708.

Herzog, K.M., R. Thum, R. Zweifel \& R. Hasler. 1997. Heat balance measurements - to quantify sap flow in thin stems only? Agri. and Forest Meteorol. 83: 75-94.

Knight, D.H., T.J. Fahey, S.W. Running, A.T. Harrison \& L.L. Wallace. 1981. Transpiration from 100-yr-old lodgepole pine forests estimated with whole-tree potometers. Ecology 62: 717-26.

Marshall, D.C. 1958. Measurement of sap flow in conifers by heat transport. Plant Physiol. 33: 385-96.

Phillips, N., R. Oren \& R. Zimmerman. 1996. Radial patterns of xylem sap flow in non-, diffuse- and ring-porous tree species. Plant, Cell \& Environ. 19: 983-90.

Pickard, W.F. 1989. How might a tracheary element that is embolized by day be healed by night? J. Theoretical Biol. 141: 259-79.

Ritchie, G.A. \& T.M. Hinckley. 1975. The pressure chamber as an instrument for ecological research. Advance Bot. Res. 9: 165-224.

Sakuratani, T. 1981. A heat balance method for measuring water flux in the stems of intact plants. J. Agri. Meteorol. 37: 9-17.

Sperry, J.S., R.J. Donnelly \& M.T. Tyree. 1988. A method for measuring hydraulic conductivity and embolism in xylem. Plant, Cell \& Environ. 11: 35-40.

Vertessy, R.A., T.J. Hatton, P. Reece, S.K. O’Sullivan \& R.G. Benyon. 1997. Estimating stand water use of large mountain ash trees and validation of the sap flow measurement technique. Tree Physiol. 17: 747-56.

Waring, R.H. \& S.W. Running. 1978. Sapwood water storage: its contribution to transpiration and effect upon water conductance through the stems of old growth Douglas fir. Plant, Cell \& Environ. 1: 131-140.

Whitmore, J.L. 1983. Ochroma lagopus (Balsa). In Janzen D.H., ed. Costa Rican Natural History. Chicago: University of Chicago, 281-82.

Wullschleger, S.D., F.C. Meinzer \& R.A. Vertessy. 1998. A critique of whole-plant water use studies in trees. Tree Physiol. 18: 499-512. 
